ENTREPRENEURSHIP AND SUSTAINABILITY ISSUES

ISSN 2345-0282 (online) http://jssidoi.org/jesi/

2019 Volume 7 Number 2 (December)

http://doi.org/10.9770/jesi.2019.7.2(32)

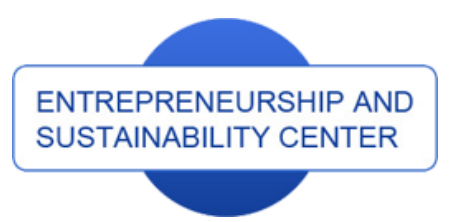

Publisher

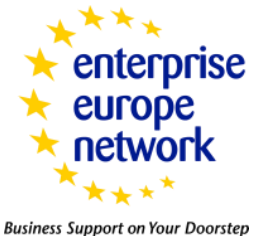

CASPA
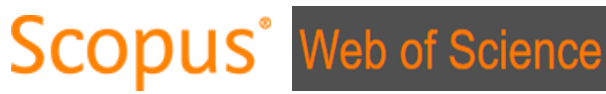

http://jssidoi.org/esc/home

Business Support on Your Doorstep

\title{
I Clarivate \\ MODELLING PROMOTION STRATEGIES IN LOCAL GOVERNMENT UNITS WITH THE APPLICATION OF STRUCTURAL EQUATION MODELLING (SEM) WITH AN EXAMPLE OF WARMIA AND MAZURY REGION*
}

\author{
Marcin Chrząścik
}

Siedlce University of Natural Sciences and Humanities, Faculty of Social Sciences, Żytnia Street 39, 08-110 Siedlce, Poland

E-mail: marcin.chrzascik@uph.edu.pl

Received 16 May 2019; accepted 15 October 2019; published 15 December 2019

\begin{abstract}
The self-government of the Warmińsko-Mazurskie Province (województwo warmińsko-mazurskie) has implemented one of the first image-centered promotion strategies in Poland to promote the region. Its promotion strategy was a result of the campaign termed "Mazury Cud Natury - The Wonder Of Nature" launched in 2009 and constituted especially by image-centered actions targeted at tourists and representatives of the surroundings of the Warmińsko-Mazurskie Province, with no specific segmentation of the remaining recipients. What is more, the "Mazury Cud Natury - The Wonder Of Nature" has been the first operation of the kind run at such a scale in Poland. Nearly all of the local government units in the Warmińsko-Mazurskie Province, supported by numerous non-profit organizations and the private sector, have become actively involved in the campaign. The paper presents the characteristics and application of sample statistical tools developed to evaluate the efficacy of the adopted promotion strategy in the above mentioned region.
\end{abstract}

Keywords: territorial marketing; promotion strategy; region; structural equation modelling

Reference to this paper should be made as follows: Chrzaścik M. 2019. Modelling promotion strategies in local government units with the application of structural equation modelling (SEM) with an example of Warmia and Mazury region. Enterpreunership and Sustainability Issues, 7(2), 1258-1278. http://doi.org/10.9770/jesi.2019.7.2(32)

JEL Classifications: M10, M30, M31, O21

\footnotetext{
* The research was carried out under the research theme No. 432/15/S financed from by a science grant provided by the Ministry of Science and Higher Education of Poland.
} 


\section{ENTREPRENEURSHIP AND SUSTAINABILITY ISSUES}

ISSN 2345-0282 (online) http://jssidoi.org/jesi/

2019 Volume 7 Number 2 (December)

http://doi.org/10.9770/jesi.2019.7.2(32)

\section{Introduction}

The new socio-economic reality presents fresh challenges and goals to local government units. Influencing one's views and attitudes through tailored measures should generate the ways of target audience behavior as expected by and in the interest of a given unit. With respect to residents, it could be, amongst other things, the creation of proper conditions of life and personal development, the development of socially accepted patterns of behavior in the area of economic and non-economic activity, the activation of local communities centered on important personal development goals, the development of individual enterprises, the promotion of cultural and historical heritage of a settlement unit, or the creation of a positive image of a given unit (Szromnik, 2008).

As a consequence of a modification of the marketing concept, new marketing fields have been created and reinforced. One of them is territorial marketing (also referred to as communal marketing) (Szromnik, 2008). Its unique underlying features are strongly related to the properties of a given location. In literature, we can also find terms such as country marketing, region marketing and city marketing.

The self-government of the Warmińsko-Mazurskie Province (województwo warmińsko-mazurskie) has implemented one of the first image-centered promotion strategies in Poland to promote the region. Its promotion strategy was a result of the campaign termed "Mazury Cud Natury - The Wonder Of Nature" launched in 2009 and constituted especially by image-centered actions targeted at tourists and representatives of the surroundings of the Warmińsko-Mazurskie Province, with no specific segmentation of the remaining recipients. This was because the region of Warmia and Mazury is a typical tourist area of Poland, of an ecological nature. Development trends, whose direct implication has become excessive exploitation of nature, maximization of world consumption, are being questioned today by experts pointing out the social costs of these processes. The care for the future, for the common good of future generations is beginning to be defined by social researchers in terms of civilizational challenges. It's worth to add, that ecological problems treated as direct implications of unchecked technological advancement, devoid of any reflection on the condition of civilization, are tackled by representatives of all science disciplines (Jucker, Mathar 2015; Ul Haque 2019; Tkachenko et al. 2019; Polozova et al. 2019; Smaliukiené, Monni 2019). What is more, the "Mazury Cud Natury - The Wonder Of Nature" has been the first operation of the kind run at such a scale in Poland. Nearly all of the local government units in the Warmińsko-Mazurskie Province, supported by numerous non-profit organizations and the private sector, have become actively involved in the campaign. Today, despite the fact that the campaign is over and the authorities of the WarmińskoMazurskie Province are pursuing yet another marketing strategy, we continue to see the effects and impact of the "Mazury Cud Natury - The Wonder Of Nature" campaign on the image of the Warmia and Mazury region. One aspect worth notice is that the described campaign has become an inspiration for other provinces which draw on the experience of the authorities of the Warmińsko-Mazurskie Province to pursue their own promotion strategies. Given the above and the results of pilot studies, the focus of the study was the analysis of the image of the Warmia and Mazury region.

The author concentrated on the analyses pertaining to the Warmińsko-Mazurskie Province, which is an equivalent of the NUTS 2 level and which, for geographic and historic reasons, is referred to as the Warmia and Mazury region.

The research goal was to determine the strategic factors of the strategy of promotion applied in the region. The research paper comprises author's own research findings. In the key phase of the research process, an empirical research method in the form of a diagnostic survey with a questionnaire technique and a survey were employed.

Upon research data collection, a research process followed, which involved statistical methods and techniques. The statistical analysis of the research results performed with the use of the Statistica 9.1 package (StatSoft, 2010), the principal method applied was the Structural Equation Modelling (SEM) with the use of exploratory 


\section{ENTREPRENEURSHIP AND SUSTAINABILITY ISSUES}

ISSN 2345-0282 (online) http://jssidoi.org/jesi/

2019 Volume 7 Number 2 (December)

http://doi.org/10.9770/jesi.2019.7.2(32)

factor analysis (EFA) to uncover the correlated groups of potential strategic factors having an impact on the effectiveness of the pursued promotion strategy. The use of the specified methods have allowed the author to determine which of the potential factors are of strategic nature.

\section{The Use of Promotion Strategy in the Creation of Territorial Unit's Image}

In the times of increasingly intense competition for gaining investors', residents' and tourists' interest, the issues associated with the promotion of local government units are becoming ever more important. This is because promotional activities may boost the exposition of given unit's key resources and, consequently, promote longterm regional development.

The implementation of marketing actions requires suitable planning and coordination. A marketing strategy is a set of foreseeable marketing undertakings with the application of which a settlement unit intends to affect certain groups of recipients. Territorial units (local governments) conduct multi-stage activities aimed at increasing the efficacy of implemented strategies.

Analyzing is the first stage of the marketing strategy where needs and expectations of the target audience on both the internal and external markets are analyzed (Domański, 1997). It is simultaneously the stage of analysis of the potential of a given local community against the background of the potential of any neighboring communes, cities and regions (the effect of competitiveness or complementarity of local resources).

Planning is the second, most elaborated stage, involving the planning of factual actions regarding the policy of development of a given community in various aspects and with respect to diverse groups of recipients (market segments analyzed at stage one). At this stage, general goals and directions of strategic development of a given local community are set. It often seems to be underestimated, despite its leading role for the strategy's cohesiveness. The lack of a clear guideline and the direction of development leads to resource dispersion and an impasse. Extensive consultations are required here, including a number of communities and institutions forming the network of local relations.

For a marketing plan to become implemented as expected, all of the above specified stages should be accomplished with the strong support of external companies, such as advertising and marketing agencies etc.

The final stage, supervision, is observation of actions in the phase of marketing strategy implementation. Supervision should be conducted both by external institutions, such as special local government committees, independent expert bodies, and independent advisory companies (Domański, 1997). One ought to carefully watch whether the actions are conducted according to schedule and whether they are headed in the direction prescribed in the first place.

There is a number of bodies involved in the creation of an image of a local government unit: local authorities, organizations, associations and enterprises operating in the territory of a given unit, residents, mass media and tourists (Grzegorczyk, Kochaniec, 2010).

Local authorities and residents are those who have the most considerable impact on the creation of an image of a unit. The policy of the authorities shapes the way in which a city is perceived and assessed and points at the direction of its development. Moreover, promotion policy also has an influence on one's image, for not only the real offer but also its projection and highlighted features are of importance.

Promotion activities should be oriented, i.e. they may not include too many target groups. It is worth noting that the message on which a desired image communication need to be based should be concise and consistent. 


\section{ENTREPRENEURSHIP AND SUSTAINABILITY ISSUES}

ISSN 2345-0282 (online) http://jssidoi.org/jesi/

2019 Volume 7 Number 2 (December)

http://doi.org/10.9770/jesi.2019.7.2(32)

Every step in the process ought to be driven by the use, in varying proportions, of the instruments of image promotion, such as: advertising, public relations, direct marketing, personal sales, etc. (Glińska, Florek, Kowalewska, 2009). Having specified the instruments used to build a desired image, persons and cells responsible for the implementation of individual tasks must be appointed.

All of the above actions are aimed at influencing the effectiveness of the image as much as possible. Despite the widespread use of the term 'efficiency' in relation to the functioning of an organization, there are still some difficulties in defining it. E. Skrzypek defines efficiency as the ability of each organization to implement strategies and achieve planned goals. The author emphasizes that it depends on doing a good job and the right things in the right way (Skrzypek 2000, Chrząścik 2018).

\section{Description of Author's Research of Promotion Strategy Modelling}

Over the period 2009 - 2017, the author of the paper focused on the analysis of the effectiveness of the promotion strategy of the Warmia and Mazury region, the effect of which was the promotional campaign "Mazury Cud Natury - The Wonder Of Nature". The contents below will not account for the results of all the research but will rather be an overview of the applied structural equation modelling method. The purpose of the whole research study was to develop of models of a promotion strategy for the management of a region's image. Due to its extensiveness, the sub-chapter presents only an extract from the research in order to demonstrate the operating diagram and the research procedure. The author's earlier research allowed determining the promotion strategy used by the Warmia and Mazury region as effective. Due to the tourist nature of the region, the effectiveness of the "Mazury Cud Natury - The Wonder Of Nature" campaign was studied on entities such as tourists.

To develop and, subsequently, verify the author's models, actions were undertaken to analyze the complete process of Warmia and Mazury region's image management. One of the elements of the models are strategic determinants of the effectiveness of the strategy, which are key to the whole process under which the adopted promotion strategy is used. In the studied case, where over one hundred various entities are pursuing one strategy and at the same time have an impact (quite low) on its entire course, what is of essence is to point out groups of the above mentioned strategic factors, for they constitute the foundation for the evaluation of the effectiveness of implemented promotional activities.

In order to determine the groups of potential strategic factors affecting the effectiveness of the promotion strategy in the process of management of the Warmia and Mazury region's image, world literature and reports showing results of research on region competitiveness were analyzed. A highly interesting source of information turned out to be a publication of a team of scientists originating from three countries: Italy, Switzerland and China, which investigate the topic related to region development strategy implementation. Its authors attempted to distinguish strategic factors influencing strategy implementation in their countries. Their research findings confirm the previous conclusions, i.e. that among the strategic factors of region development are:

- organizational,

- human capital-related,

- infrastructural,

- inter-organizational partnership factors (Li, Gouhui, Eppler, 2008).

Another absorbing report supporting the choice of strategic factors to be employed in the author's model development is a document designed by the Standing Committee for Economic and Commercial Cooperation of the Organization of the Islamic Cooperation (COMCEC) entitled "Effective Tourism Marketing Strategies". Tourism in Arab countries is known to be one of the principal branches of their economies. The report comprises 
an analysis of the strategies of promotion of tourist areas, such as: Nigeria, Azerbaijan, Saudi Arabia, Turkey, Egypt and Mozambique. It further outlines how the said countries implemented into their own strategies of promotion various elements from other countries from all over the world. There, we could also find numerous valuable case studies on territorial marketing and tourism. The report presents a model of strategic factors of effectiveness of promotional activities which comprises four elements: inter-sectoral cooperation, human resources, advanced technology, managerial-organizational factors (COMEC, 2015).

Given the above specified research studies presented in world literature and reports of acknowledged organizations, the direction to establish the strategic factors responsible for the effectiveness of realization of the strategy of promotion of the Warmia and Mazury region was taken.

Finally, it was assumed that the potential strategic factors would be selected from amongst the following five groups of factors: technological factors, organizational factors, managerial factors, competence factors (associated with human resources) and factors related to inter-organizational relations.

Next, seven experts were designated, specialists for promotion in Polish Marshal Offices and, with the technique of an interview, potential strategic factors were determined. The selected detailed factor groups are presented below.

Technological factors relate to the technological capacity of an organization to generate and absorb innovative solutions in the area of promotional instrument use (see Table 1).

Table 1. Technological factors

\begin{tabular}{|l|l|}
\hline $\begin{array}{l}\text { Technological factors } \\
\text { (technology, resources, ties) }\end{array}$ \\
\hline T 1 & $\begin{array}{l}\text { Autonomous research and development involving innovative regional products, processes, } \\
\text { organizational/ marketing solutions }\end{array}$ \\
\hline T 2 & Research and development in cooperation with R\&D units, institutes and universities \\
\hline T 3 & Research and development jointly with other companies \\
\hline T 4 & Outsourcing of research and development \\
\hline T 5 & Autonomous development of promotion strategy elements \\
\hline T 6 & Team competent to produce marketing tools \\
\hline T 7 & Own technical infrastructure (hardware/software) \\
\hline T 8 & Major expenditure for marketing activities \\
\hline T 9 & Outsourcing of marketing tools \\
\hline T 10 & Use of state-of-the-art information technologies (IT) \\
\hline T 11 & Close technical cooperation with partners \\
\hline
\end{tabular}

Source: Own research.

An important element of organizational factors is work organization within an organization (amongst other things: organizational structure, system of communication). The system of work organization may not limit employee potential. Instead, it should encourage their creativity and provide opportunities for them to come up with and implement their own ideas (Table 2). 
Table 2. Organizational factors

\begin{tabular}{|l|l|}
\hline $\begin{array}{l}\text { Organizational factors } \\
\text { (organizational structure, model of cooperation with surroundings: association membership, cluster } \\
\text { initiative) }\end{array}$ \\
\hline O 1 & Size of organization and its financial resources \\
\hline O 2 & Flexible (flat) organizational structures based on task teams \\
\hline O 3 & Preference for team work \\
\hline O 4 & Clear division of tasks between employees \\
\hline O 5 & Efficient information system facilitating internal communication \\
\hline O 6 & High level of organizational structure \\
\hline O 7 & Outsourcing tasks (outsourcing, subcontractors) \\
\hline O 8 & Cooperation with other organizations in the form of associations (e.g. NGOS) \\
\hline O 9 & Cluster-membership (cluster initiative) \\
\hline O 10 & Network-membership (networking with other entities) \\
\hline
\end{tabular}

Source: Own research.

Managerial factors are associated with decisions made by the authorities of territorial units. Despite the fact that decisions relate to a number of areas of company operations (e.g. financial, HR), the key decisions are those which define the strategy of development (Table 3).

Table 3. Managerial factors

\begin{tabular}{|l|l|}
\hline $\begin{array}{l}\text { Organizational factors } \\
\text { (strategies of promotion based on: vision of authorities, innovation, benchmarking; results of image } \\
\text { research studies) }\end{array}$ \\
\hline $\mathbf{Z ~ 1 ~}$ & $\begin{array}{l}\text { Implementation of the strategy of promotion based on the local authorities' marketing } \\
\text { vision }\end{array}$ \\
\hline $\mathbf{Z ~ 2 ~}$ & $\begin{array}{l}\text { Separating from competition by searching for new tendencies in promotional and branding } \\
\text { activities }\end{array}$ \\
\hline $\mathbf{Z ~ 3}$ & Strategy of promotion based on open innovation implementation \\
\hline $\mathbf{Z ~ 4}$ & Searching for a market niche for new marketing solutions \\
\hline $\mathbf{Z ~ 5}$ & Introducing employees to the strategy of promotion based on branding research \\
\hline $\mathbf{Z ~ 6}$ & Application of good and verified solutions used by competition \\
\hline $\mathbf{Z ~ 7 ~}$ & Use of methods of project management \\
\hline $\mathbf{Z ~ 8}$ & Relation establishment as part of cooperation principles \\
\hline $\mathbf{Z ~ 9 ~}$ & $\begin{array}{l}\text { Effective use of key (most important for an organization) employee competencies of } \\
\text { employees }\end{array}$ \\
\hline $\mathbf{Z ~ 1 0}$ & Inspiring employees to look for new solutions \\
\hline $\mathbf{Z ~ 1 1}$ & Implemented system of awarding employees bonuses for innovation \\
\hline $\mathbf{Z ~ 1 2}$ & $\begin{array}{l}\text { Positive attitude of the management to state-of-the-art solutions as part of promotion } \\
\text { instrument use }\end{array}$ \\
\hline $\mathbf{Z ~ 1 3}$ & Continuity of organization's management \\
\hline
\end{tabular}

\section{Competency factors}

Source: Own research.

The competency-based organization involves that competencies, as strategic resources, precondition organization's survival and development and constitutes the foundation for gaining a lasting competitive advantage. Gaining competitive advantage depends, to a large extent, on the skills relating to knowledge, experience and skill acquisition and application (Table 4). 
Table 4. Competency factors

\begin{tabular}{|l|l|}
\hline $\begin{array}{l}\text { Competency factors } \\
\text { (intelligent organization, intellectual capital, knowledge, know-how, learning by doing, } \\
\text { crowdsourcing) }\end{array}$ \\
\hline K 1 & Knowledge and technological competencies of company management \\
\hline K 2 & High qualifications of the management staff \\
\hline K 3 & High technological competencies of employees \\
\hline K 5 & High employee skills in the area of management \\
\hline K 6 & Employee tacit knowledge sharing \\
\hline K 7 & $\begin{array}{l}\text { Managing a portal to allow knowledge exchange between cooperating employees of the } \\
\text { organization }\end{array}$ \\
\hline K 8 & Organization knowledge management (knowledge banks, knowledge portals) \\
\hline K 9 & Good insight into the market and behavior of competition \\
\hline K 10 & Learning by doing \\
\hline K 11 & Acquisition of know how-type knowledge \\
\hline K 12 & Employee participation in practical placements and internships outside the organization \\
\hline K 13 & $\begin{array}{l}\text { A system of incentives and financial support for employees furthering their qualifications } \\
\text { (courses, training, postgraduate studies) }\end{array}$ \\
\hline K 14 & Employee participation in academic symposia and conferences \\
\hline
\end{tabular}

Source: Own research.

Formal and informal ties of an organization within and outside the industry were included in the factors related to inter-organizational ties (Table 5).

Table 5. Factors related to inter-organizational ties

\begin{tabular}{|l|l|}
\hline \multicolumn{2}{|l|}{ Factors related to inter-organizational ties } \\
\hline P 1 & Ties under provincial administration \\
\hline P 2 & Ties under a strategic alliance \\
\hline P 3 & Ties under a non-profit organization \\
\hline P 4 & Ties under the special economic zone \\
\hline P 5 & Ties under scientific research contracts \\
\hline P 6 & Ties under a self-regulatory organization \\
\hline P 7 & Territorial ties \\
\hline P 8 & Ties under a self-regulatory organization \\
\hline P 9 & Informal ties - friendships with other company leaders \\
\hline P 10 & Informal ties - contacts made at fairs \\
\hline P 11 & Informal ties with academic staff \\
\hline P 12 & Informal ties - close links to the end-user \\
\hline P 13 & Cooperation with other companies \\
\hline P 14 & Economic chamber, professional association membership \\
\hline
\end{tabular}

Source: Own research.

According to data presented in PWN Encyclopaedia and regarding Poland's administrative division, the Warmińsko-Mazowieckie Province is composed of 19 poviats, 16 urban communes, 33 urban-rural communes and 67 rural communes. In the course of the cognitive process, the following local authorities were selected for research purposes: Marshal Office (Urzad Marszalkowski) in Olsztyn (Department for Promotion Coordination and Departament of Tourism), 19 Poviat Starost's Offices (starostwo powiatowe), 16 Town Councils (urzad miejski) and 100 Commune Offices (urzad gminy). The entities totaled to 135 local authorities. The research covered all of the local authorities. As a result, 111 correctly filled surveys were collected, including surveys from 
ENTREPRENEURSHIP AND SUSTAINABILITY ISSUES

ISSN 2345-0282 (online) http://jssidoi.org/jesi/

2019 Volume 7 Number 2 (December)

http://doi.org/10.9770/jesi.2019.7.2(32)

the Marshal Office, 16 Poviat Starost's Offices (84.2\%), 13 Town Councils (81.25\%) and 81 Commune Offices $(81 \%)$.

Several distribution channels were employed in order to disseminate the survey in the research proceedings. The first method of evidence collected was to conduct an interview with a single respondent. The majority of the cases were conducted by phone. Furthermore, the contents of the survey with the request to complete it were posted online.

\section{Methodology of author's own analysis of promotion strategy modelling with the application of structural equation modelling on a selected group of factors}

Upon research data collection, the last stage of the research process followed, which involved statistical methods and techniques. In order to determine the potential strategic factors of promotion strategy effectiveness, the author decided to use the so-called exploratory factor analysis (EFA), as suggested by, amongst others, T. Asparouhov and B. Muthen (Asparouhov, Muthen, 2009). The application of the method (by principal component analysis) led to the limitation of the large group of primary factors. Thereby, potential strategic factors specified further on have been listed.

In the overview of the analysis, it must be said that respondents carried out an assessment of the strategic importance of primary variables for promotion effectiveness in the scale from 1 to 5 . The method applied to isolate the principal components with the Varimax rotation allowed the author to distinguish three principal components which were further tested with the Structural Equation Modelling. The objective of the analysis was to determine the power of the strategic factor relationship and the level of its impact on the strategy of promotion in a given province.

The basis for the structural equation modelling (SEM) were the results of both empirical studies and the conducted exploratory factor analysis (EFA).

Further on in these considerations, the idea of a factor will stand for a latent (non-observable) variable representing one or more observable primary variables. Structural equation modelling is one of the statistical methods used to examine the relationships among observable variables and factors involving non-observable causality of a factor. The method enables one to analyze the cause and effect relationships, as in the case of regression analysis, and additionally - to conduct an analysis of correlations.

The structural equation model developed on the basis of observable variables is a general statistical model, the special cases of which are regression analysis (simple, multiple and complex), ANOVA (and MANOVA and ANCOVA), path analysis and econometric models. The number of equations in a model equals the number of endogenous variables in the model. Equations are solved for endo- and exogenous variables observed directly without error.

Assuming (by way of an example), that there are two endogenous variables and three exogenous variables, and that some parameters in the structural matrices $\mathbf{B}$ and $\boldsymbol{\Gamma}$ are zero, the structural equation model shall be expressed as follows in matrix form (Konarski, 2019):

$$
\begin{gathered}
{\left[\begin{array}{l}
y_{1} \\
y_{2}
\end{array}\right]=\left[\begin{array}{cc}
0 & 0 \\
\beta_{21} & 0
\end{array}\right]+\left[\begin{array}{l}
y_{1} \\
y_{2}
\end{array}\right]=\left[\begin{array}{ccc}
\gamma_{11} & 0 & 0 \\
0 & \gamma_{22} & \gamma_{23}
\end{array}\right]\left[\begin{array}{l}
x_{1} \\
x_{2} \\
x_{3}
\end{array}\right]+\left[\begin{array}{l}
\xi_{1} \\
\xi_{2}
\end{array}\right]} \\
=\left[\begin{array}{c}
\gamma_{11} x_{1}+\xi_{1} \\
\beta_{21} y_{1}+\gamma_{22} x_{2}+y_{23} x_{3}+\xi_{2}
\end{array}\right]
\end{gathered}
$$


The above presented model of structural equations can be depicted in the way shown in Figure 1.

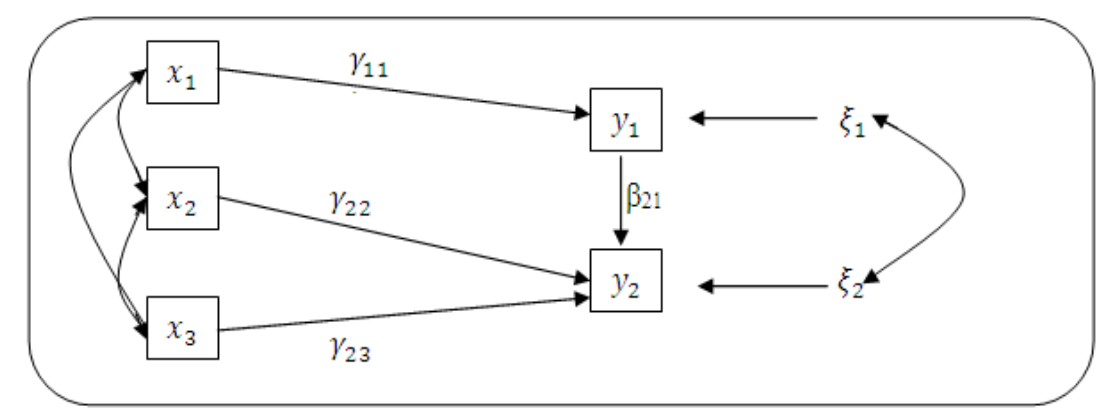

Fig. 1. Graphic representation of a two-equation structural equation modelling for observable variables

Source: R. Konarski, Modele równań strukturalnych. Teoria i praktyka, Wydawnictwo Naukowe PWN, Warszawa 2019 , p. 126.

Thus, the structural equation model may be depicted either in the form of a set of equations or a graphic scheme. In this study, the graphic representation has been adopted and the following common designations have been assigned to all of the below shown model diagrams:

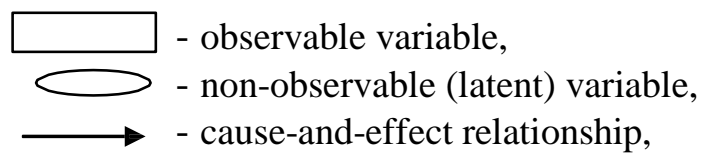

- the figure above the arrow stands for the path co-efficient,

- the figure next to the observable variable stands for the R2 determination co-efficient,

- $\mathrm{e}$ - is a random component of a variable.

To model the structural equations, Statsoft Statistica 9.1 was employed. To design the graphic representation of the model, Navicat Data Modeler Essentials was used.

\section{Underlying research and research findings. Verification of the employed statistical methods.}

Respondents performed an evaluation of strategic importance of primary variables for promotion effectiveness on a scale from 1 to 5 . The results of respondent assessment of individual indicators are presented in the tables below.

The calculations show that the applied method of isolating principal components with the Varimax rotation allowed to distinguish principal components with eigenvalues higher than 1 and accounting in total for over $60.7 \%$ of factor variability.

Therefore, the exploratory factor analysis conducted on the basis of the resultant empirical data and the principal component analysis (PCA) allowed to distinguish the principal components, i.e. new, non-correlated factors which preserve the maximum of the original data variation. The said factors are found to be initial potential strategic factors of promotion strategy efficacy, each of which groups specific primary variables.

The potential strategic factors of promotion strategy efficacy are presented below (Table 6, Table 7, Table 8, Table 9, Table 10): 
Table 6. Specification of potential technological strategic factors and primary variables

\begin{tabular}{|l|l|l|}
\hline \multirow{3}{*}{ Factor } & \multicolumn{2}{|l|}{ Primary variable } \\
\hline CT1 & T 4 & Outsourcing of research and development \\
\cline { 2 - 3 } & T 9 & Outsourcing of marketing tools \\
\cline { 2 - 3 } & T 10 & Use of state-of-the-art information technologies (IT) \\
\cline { 2 - 3 } & T 11 & Close technical cooperation with partners \\
\hline CT2 & T 1 & $\begin{array}{l}\text { Autonomous research and development involving innovative regional products, } \\
\text { processes, organizational/ marketing solutions }\end{array}$ \\
\cline { 2 - 4 } & T 2 & Research and development in cooperation with R\&D units, institutes and universities \\
\cline { 2 - 4 } & T 3 & Research and development jointly with other companies \\
\hline \multirow{5}{*}{ CT3 } & T 5 & Autonomous development of promotion strategy elements \\
\cline { 2 - 4 } & T 6 & Team competent to produce marketing tools \\
\cline { 2 - 3 } & T 7 & Own technical infrastructure (hardware/software) \\
\cline { 2 - 3 } & T 8 & Major expenditure for marketing activities \\
\hline
\end{tabular}

Source: Own research.

Table 7. Specification of potential organizational strategic factors and primary variables

\begin{tabular}{|l|l|l|}
\hline \multirow{2}{*}{ Factor } & \multicolumn{2}{|l|}{ Primary variable } \\
\hline \multirow{2}{*}{ O1 } & O 5 & Efficient information system facilitating internal communication \\
\cline { 2 - 3 } & O 6 & High level of organizational culture \\
\hline CO2 & O 7 & Outsourcing tasks (outsourcing, subcontractors) \\
\cline { 2 - 3 } & O 10 & Network-membership (networking with other entities) \\
\hline CO3 & O 1 & Size of organization and its financial resources \\
\cline { 2 - 3 } & O 9 & Cluster-membership (cluster initiative) \\
\hline CO4 & O 3 & Preference for team work \\
\cline { 2 - 3 } & O 4 & Clear distribution of tasks among employees \\
\hline
\end{tabular}

Source: Own research.

Table 8. Specification of potential managerial strategic factors and primary variables

\begin{tabular}{|l|l|l|}
\hline Factor & \multicolumn{2}{|l|}{ Primary variable } \\
\hline CZ1 & Z 2 & $\begin{array}{l}\text { Separating from competition by searching for new tendencies in promotional and } \\
\text { branding activities }\end{array}$ \\
\cline { 2 - 3 } & Z 3 & Strategy of promotion based on open innovation implementation \\
\cline { 2 - 3 } & $\mathbf{Z ~ 4}$ & Searching for a market niche for new marketing solutions \\
\cline { 2 - 3 } & $\mathbf{Z ~ 8}$ & Establishment of relations as part of cooperation principles \\
\cline { 2 - 3 } & $\mathbf{Z ~ 9 ~}$ & $\begin{array}{l}\text { Effective use of key (most important for an organization) employee competencies of } \\
\text { employees }\end{array}$ \\
\hline \multirow{4}{*}{ CZ2 } & Z 5 & Introducing employees to the strategy of promotion based on branding research \\
\cline { 2 - 3 } & Z 12 & $\begin{array}{l}\text { Positive attitude of the management to state-of-the-art solutions as part of promotion } \\
\text { instrument use }\end{array}$ \\
\cline { 2 - 3 } & Z 13 & Continuity of organization's management \\
\hline CZ3 & $\mathbf{Z ~ 1 0}$ & Inspiring employees to look for new solutions \\
\cline { 2 - 3 } & Z 11 & Implemented system of awarding employees bonuses for innovation \\
\hline
\end{tabular}

Source: Own research. 
Table 9. Specification of potential competence strategic factors and primary variables

\begin{tabular}{|c|c|c|}
\hline Factor & \multicolumn{2}{|c|}{ Primary variable } \\
\hline \multirow[t]{5}{*}{ CK1 } & K 1 & Knowledge and technological competencies of company management \\
\hline & K 2 & High qualifications of the management staff \\
\hline & K 8 & Organization knowledge management (knowledge banks, knowledge portals) \\
\hline & K 9 & Good insight into the market and behavior of competition \\
\hline & K 11 & Acquisition of know how-type knowledge \\
\hline \multirow[t]{3}{*}{ CK2 } & K 7 & $\begin{array}{l}\text { Managing a portal to allow knowledge exchange between cooperating employees of the } \\
\text { organization }\end{array}$ \\
\hline & K 13 & $\begin{array}{l}\text { A system of incentives and financial support for employees furthering their } \\
\text { qualifications (courses, training, postgraduate studies) }\end{array}$ \\
\hline & K 14 & Employee participation in academic symposia and conferences \\
\hline \multirow[t]{2}{*}{ CK3 } & K 3 & High technological competencies of employees \\
\hline & K 5 & High employee skills in the area of marketing \\
\hline
\end{tabular}

Source: Own research.

Table 10. Specification of potential inter-organizational ties-related strategic factors and primary variables

\begin{tabular}{|l|l|l|}
\hline \multirow{2}{*}{ Factor } & Primary variable \\
\hline CP1 & P 1 & Ties under provincial administration \\
\cline { 2 - 3 } & P 4 & Ties under the special economic zone \\
\hline \multirow{2}{*}{ CK3 } & P 9 & Informal ties - friendships with other company leaders \\
\cline { 2 - 3 } & P 14 & Economic chamber, professional association membership \\
\hline \multirow{2}{*}{ CP2 } & P 11 & Informal ties with academic staff \\
\cline { 2 - 3 } & P 12 & Informal ties - close links to the end-user \\
\hline
\end{tabular}

\section{Source: Own research.}

The next stage of the research involved an analysis of the newly acquired strategic factors, as presented below:

CT1 - Company external activity and use of state-of-the-art technologies

CT2 - Research \& development activity

CT3 - Own personnel resources and technical infrastructure and own budget for promotion activities

CO1 - High level of organizational culture based on efficient communication system

CO2 - Cooperation and outsourcing need

$\mathbf{C O 3}$ - Active cooperation with a view to developing strategic organizational position

CZ1 - Openness to an innovative approach to promotional campaign management

CZ2 - Management that is stable and has a positive attitude to modern tool application

$\mathbf{C Z 3}$ - Management that has leadership competencies with respect to promotion strategy implementation

CK1 - High competencies of the management with respect to technology and organization's knowledge management

CK2 - Use of modern systems of employee knowledge exchange and use of motivation factors

CK3 - Employee specialist knowledge and experience

CP1 - Inter-relations among territorial and industry units

CP2 - Informal ties with academic staff 
The next step involved an analysis of the degree of power of the cause-and-effect relationships among the strategic factors with the application of the structural equation modelling method. The below presented models of structural equations have been developed for the purpose of the study.

As mentioned before, to model the structural equations, Statsoft Statistica 9.1 was employed. To design the graphic representation of the model, Navicat Data Modeler Essentials was used.

As presented in the Diagram 1, in MODEL 1, pertaining to the impact of technological strategic factors on promotion strategy efficacy, within the measurement models we can find relatively strong and statistically significant relations between each of the exogenous variables (CT1, CT2, CT3) and the primary variables which explain them.

Thus, on the basis of the results of the study, we ought to assume that the strategic determinants of promotion strategy efficacy, i.e. the factors having the most significant positive effect on the efficacy of the promotion strategy, in the area of technological factors are:

CT2 - Research \& development activity

CT3 - Own personnel resources and technical infrastructure and own budget for promotion activities

*DS signifies EFFICACY of a strategy of promotion implemented by territorial units of Warmia and Mazury

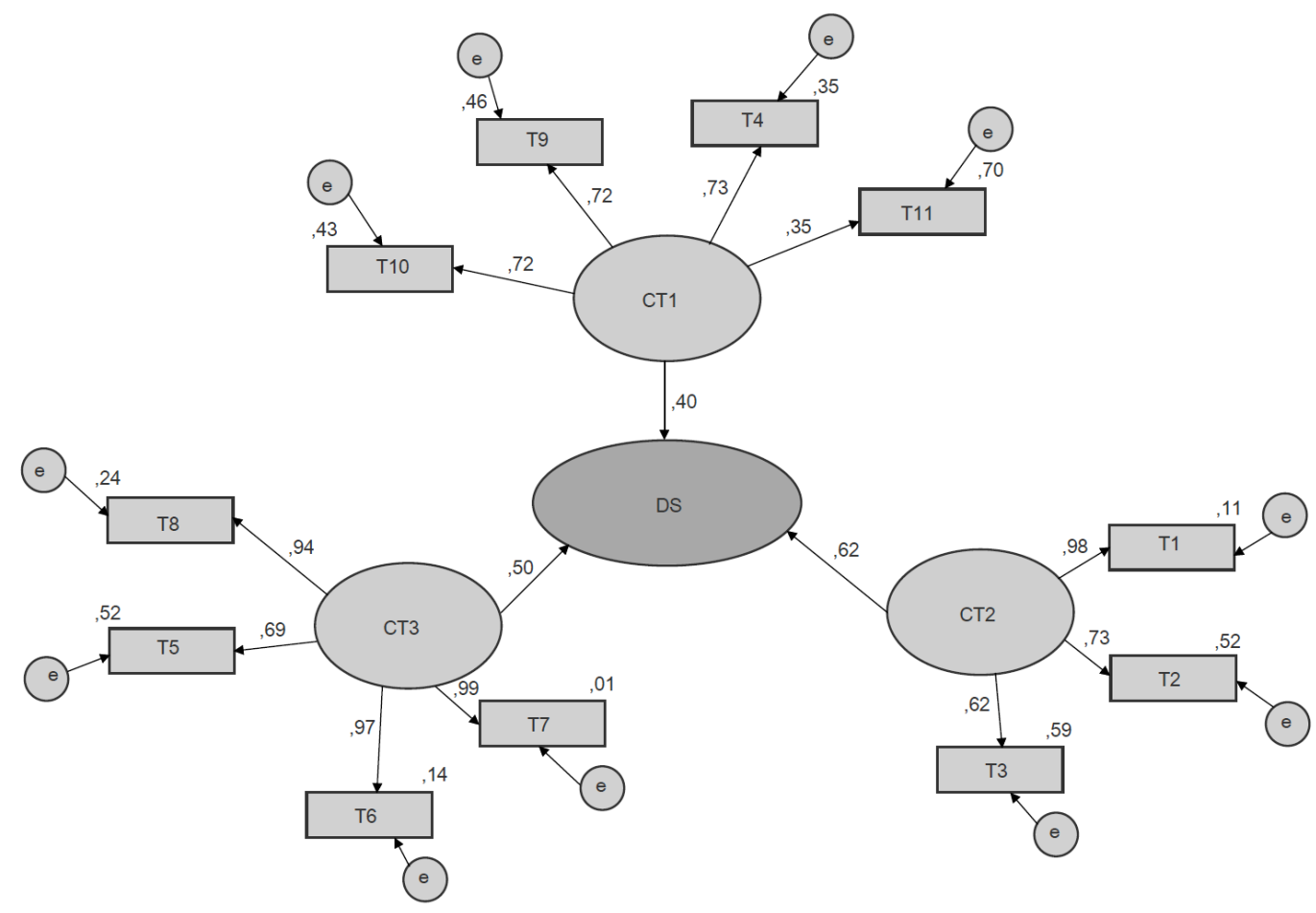

Diagram 1. Model of technological factors on the efficacy of the promotion strategy Source: Own research. 
In MODEL 2, which refers to the impact of potential strategic factors of promotion strategy efficacy organizational factors - on the efficacy of the promotion strategy, presented in Diagram 2, factors CO1, CO2, $\mathrm{CO} 3, \mathrm{CO} 4$ were included as latent exogenous variables.

Therefore, on the basis of the results of the study, we ought to assume that the strategic determinants of promotion strategy efficacy, i.e. the factors having the most significant positive effect on the efficacy of the promotion strategy, in the area of organizational factors are:

CO1 - High level of organizational culture based on efficient communication system explained by the following variables: Efficient information system facilitating internal communication; High level of organizational culture.

CO4 - Transparency of the rules of operation based on team-building explained by the following variables: Preference for team work; Clear distribution of tasks among employees.

(verte).

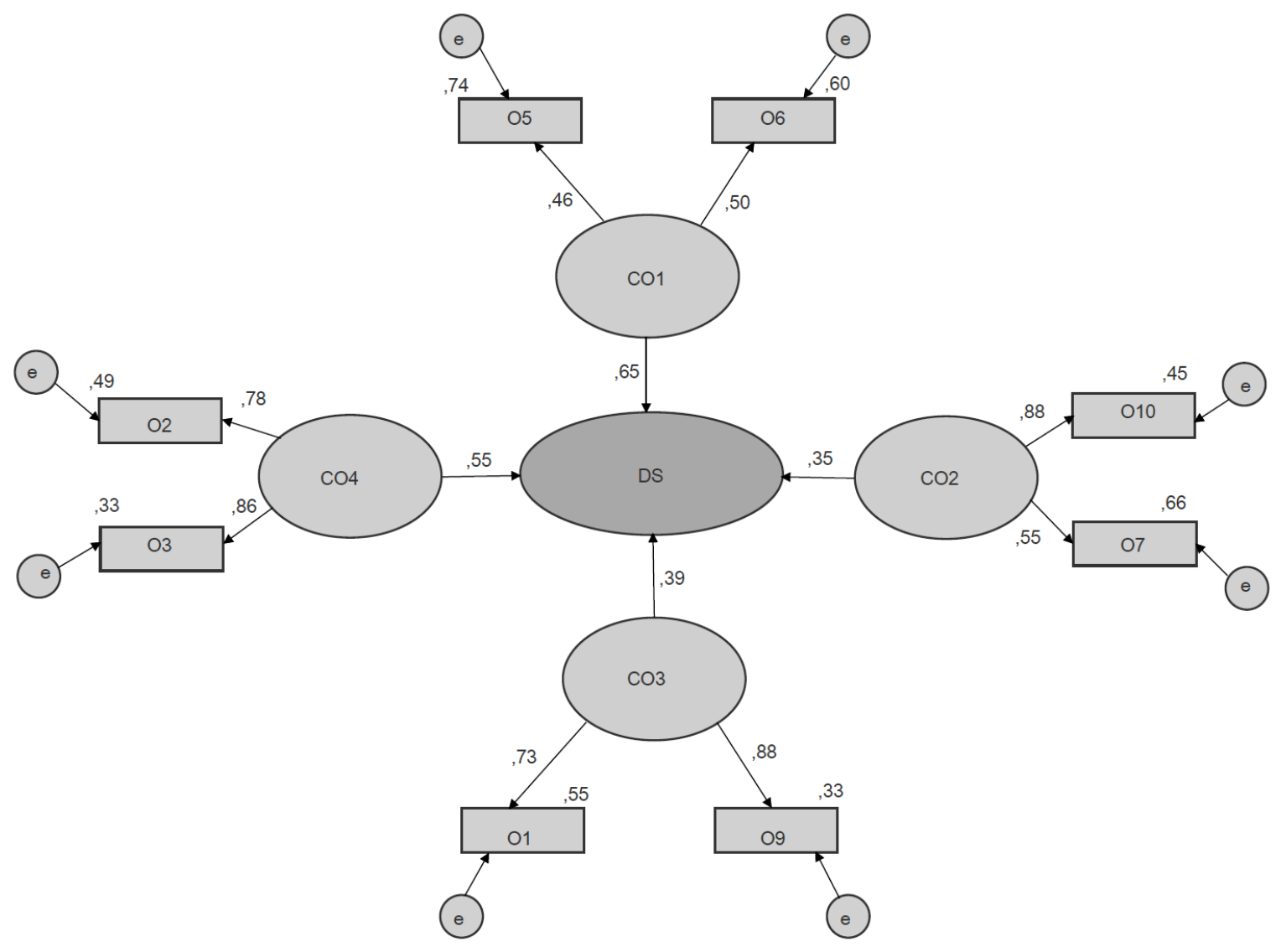

Diagram 2. Model of organizational factors on the efficacy of the promotion strategy Source: Own research. 
In MODEL 3, which refers to the impact of potential strategic factors of promotion strategy efficacy managerial factors - on the efficacy of the promotion strategy, presented in Diagram 3, factors CZ1, CZ2, CZ4 were included as latent exogenous variables.

Based on the results of the study, we ought to assume that the strategic determinants of promotion strategy efficacy, i.e. the factors having the most significant positive effect on the efficacy of the promotion strategy, in the area of managerial factors are:

CZ1 - Openness to an innovative approach to promotional campaign management explained by the following variables: Separating from competition by searching for new tendencies in promotional and branding activities; Strategy of promotion based on open innovation implementation; Searching for a market niche for new marketing solutions; Establishment of relations as part of cooperation principles; Effective use of key (most important for an organization) employee competencies of employees

CZ2 - Management that is stable and has a positive attitude to modern tool application explained by the following variables: Introducing employees to the strategy of promotion based on branding research Positive attitude of the management to state-of-the-art solutions as part of promotion instrument use Continuity of organization's management

CZ3 - Management that has leadership competencies with respect to promotion strategy implementation explained by the following variables: Inspiring employees to look for new solutions Implemented system of awarding employees bonuses for innovation

(verte). 


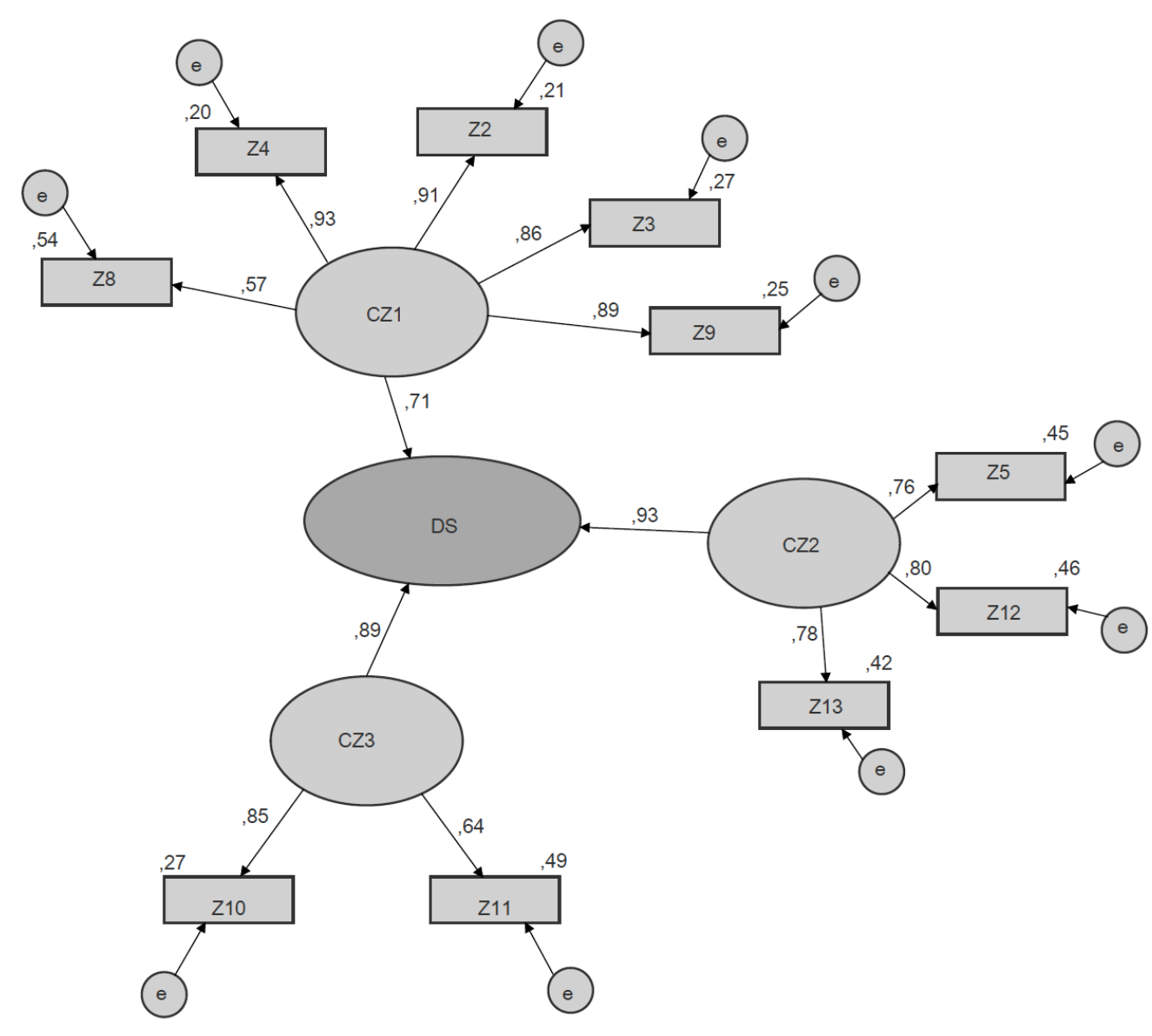

Diagram 3. Model of managerial factors on the efficacy of the promotion strategy Source: Own research.

In MODEL 4, which refers to the impact of competency potential strategic factors of promotion strategy efficacy - competency factors - on the efficacy of the promotion strategy, presented in Diagram 4, factors CK1, CK2, CK3 were included as latent exogenous variables.

Based on the results of the study, we ought to assume that the strategic determinants of promotion strategy efficacy, i.e. the factors having the most significant positive effect on the efficacy of the promotion strategy, in the area of competency factors are:

CK1 - High competencies of the management with respect to technology and organization's knowledge management explained by the variables: Knowledge and technological competencies of company management; High qualifications of the management staff; Organization knowledge management (knowledge banks, knowledge portals); Good insight into the market and behavior of competitors; Acquisition of know how-type knowledge

CK2 - Use of modern systems of employee knowledge exchange and use of motivation factors explained by the following variables: Managing a portal to allow knowledge exchange between cooperating employees of the 
organization; A system of incentives and financial support for employees furthering their qualifications (courses, training, postgraduate studies); Employee participation in academic symposia and conferences.

CK3 - Employee specialist knowledge and experience described by the following variables: High technological competencies of employees; High employee skills in the area of marketing.

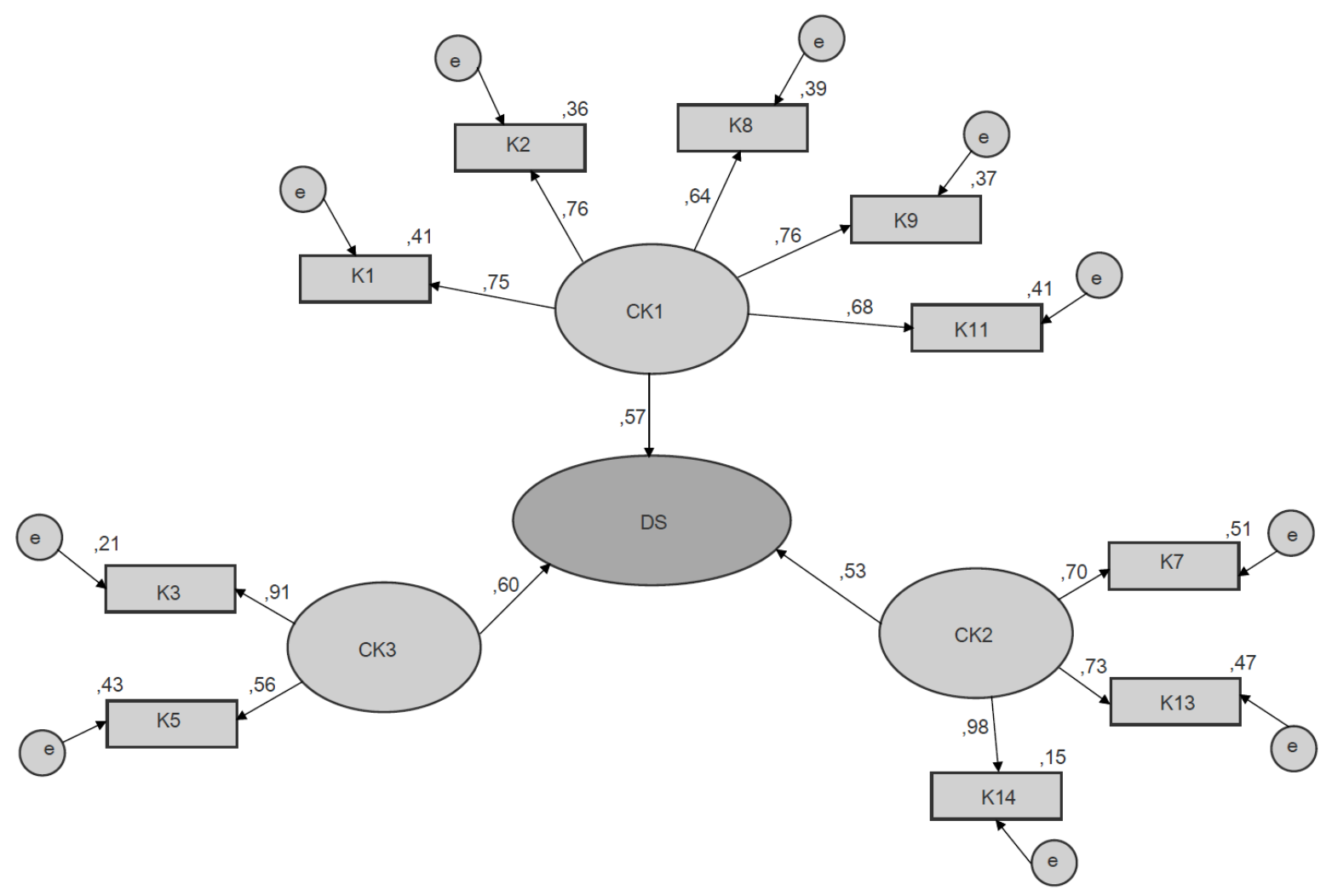

Diagram 4. Model of competency factors on the efficacy of the promotion strategy Source: Own research.

In MODEL 5, which refers to the impact of potential strategic factors of promotion strategy efficacy - factors related to inter-organizational ties - on the efficacy of the promotion strategy, presented in Diagram 5, factors $\mathrm{CP} 1, \mathrm{CP} 2$ were included as latent exogenous variables.

On the basis of the study results, we need to assume that the strategic determinants of promotion strategy efficacy, i.e. the factors having the most significant positive effect on the efficacy of the promotion strategy, in the area of factors related to inter-organizational ties are: 
CP1 - Inter-relations among territorial and industry units described by the following variables: Ties under provincial administration; Ties under the special economic zone; Informal ties - friendships with other company leaders; Economic chamber, professional association membership

CP2 - Informal ties with academic staff: Informal ties with academic staff; Informal ties - close links to the enduser.

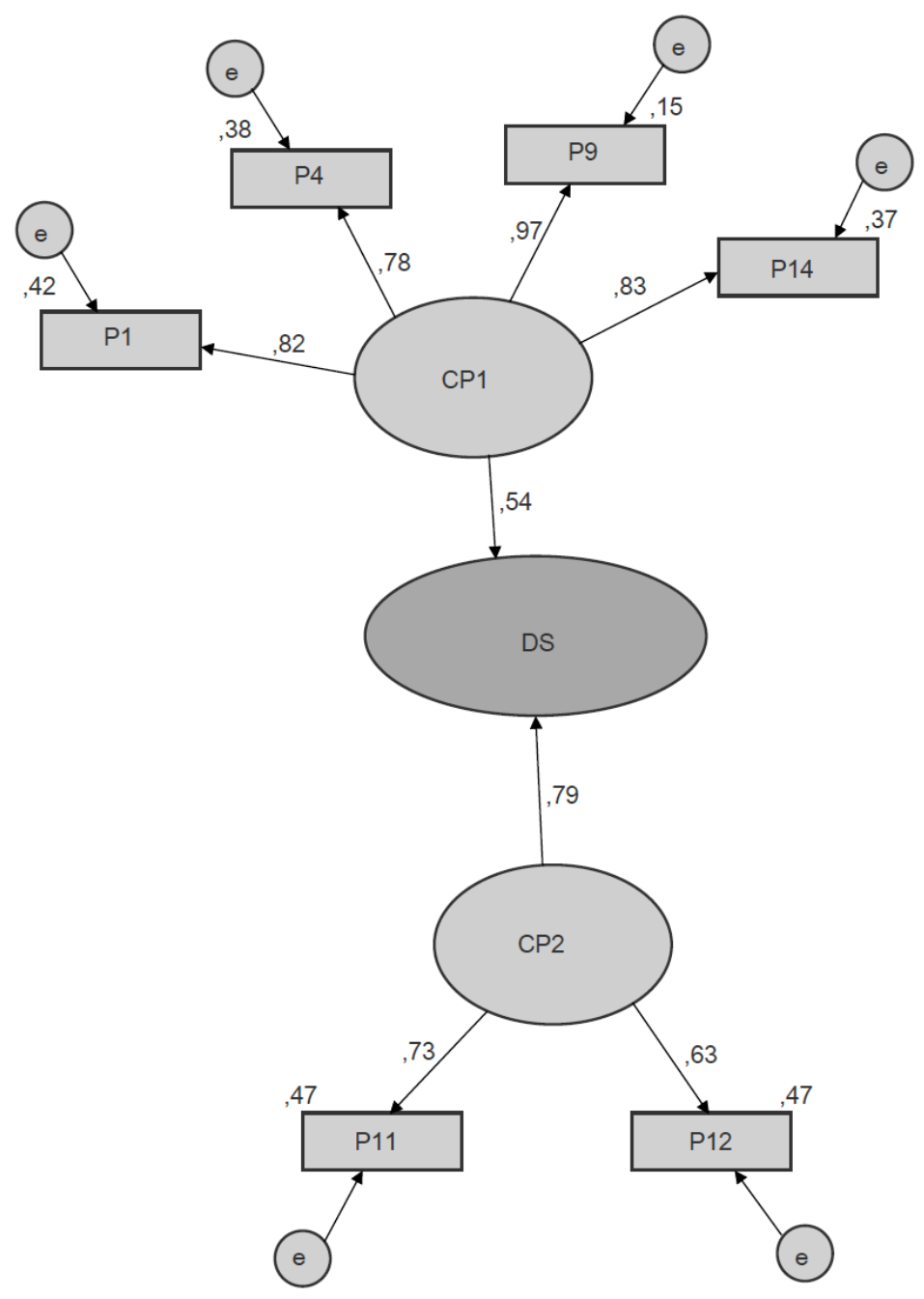

Diagram 5. Model of iter-organizational factors on the efficacy of the promotion strategy Source: Own research

\section{Summary of the research results and recommendations for the future}

The results of own empirical research presented in the study allow one to adopt the author's promotion strategy models in the management of region's image. The presented models, on the one hand, considers the selected strategic determinants of efficacy of the implemented promotion strategy, and on the other hand, identifie 


\section{ENTREPRENEURSHIP AND SUSTAINABILITY ISSUES}

ISSN 2345-0282 (online) http://jssidoi.org/jesi/

2019 Volume 7 Number 2 (December)

http://doi.org/10.9770/jesi.2019.7.2(32)

consecutive stages of the process of region's image management. As depicted by the models presented in diagrams, the strategic determinants of efficacy of the strategy of promotion pursued by territorial units of the Warmińsko-Mazurskie Province are:

- High level of organizational culture based on efficient communication system (CO1),

- Transparency of the rules of operation based on team-building (CO4),

- Research \& development activity (CT2),

- Own personnel resources and technical infrastructure and own budget for promotion activities (CT3),

- Openness to an innovative approach to promotional campaign management (CZ1),

- Management that is stable and has a positive attitude to modern tool application (CZ2),

- Management that has leadership competencies with respect to promotion strategy implementation (CZ3),

- High competencies of the management with respect to technology and organization's knowledge management (CK1),

- Use of modern systems of employee knowledge exchange and use of motivation factors (CK2),

- Employee specialist knowledge and experience (CK3),

- Inter-relations among territorial and industry units (CP1),

- Informal ties with academic staff (CP2).

OF the above specified twelve identified strategic determinants of promotion strategy efficacy, we may further distinguish five determinants with the strongest impact on the effectiveness of the implemented strategy of promotion. In the process of data analysis, five determinants - the strongest elements of the structural equation models - were singled out.

They include the following:

- High level of organizational culture based on efficient communication system (CO1),

- Research \& development activity (CT2),

- Management that is stable and has a positive attitude to modern tool application (CZ2),

- Employee specialist knowledge and experience (CK3),

- Informal ties with academic staff (CP2).

The identification of strategic determinants of promotion strategy efficacy in companies is crucial not only from the theoretical but also practical point of view, for it allows formulation of concrete guidelines for managers interested in changing company image and managing region's image with the use of promotion strategies. The empirical research conducted proved that the above listed strategic determinants are an aspect of utmost importance in the application of region's strategy of promotion.

The conceptual model design - the model underlying the research model - was based on identified strategic determinants of the implemented promotion strategy in the Region of Warmia and Mazury. Strategic determinants are understood to be the vital internal factors having a positive impact on the degree of implementation of the strategy of promotion in the aspect of region's image management and the efficiency of the phenomenon.

\section{Conclusions}

One of the elements of marketing mix in territorial terms is promotion, which is an instrument used to create the image. A large part of promotional activities used by territorial marketing entities, aimed at improving the image of territorial units, can be classified as ill-considered and ineffective as well as having no intended effects.

Despite everything, the dynamic development of marketing activities carried out by local governments has been observed for several years, which in this way want to attract various target groups to their cities and regions. 


\section{ENTREPRENEURSHIP AND SUSTAINABILITY ISSUES}

ISSN 2345-0282 (online) http://jssidoi.org/jesi/

2019 Volume 7 Number 2 (December)

http://doi.org/10.9770/jesi.2019.7.2(32)

Promotional campaigns, which we are both witnesses and recipients no longer surprise anyone. Territorial units have adopted an active attitude in building the image of their own brands.

Well thought-out strategic activities in the field of self-government promotion are increasingly encountered. Advertising in the media, visual identification systems and the organization of promotional events in various types of cities are becoming everyday life. Some of them have even become the heroes or background of feature films and series, thus becoming iconic places where many groups of tourists, potential residents or investors want to come to.

The inspiration to take up the subject of managing the image of the Warmia and Mazury region were both cognitive considerations and the lack of proposals for systemic solutions for comprehensive promotional activities in the administrative structure of provinces so far, which makes it possible to give the article an application character.

Analysis, research and explications performed as part of the study focused on the promotion strategy model in the management of the Warmia and Mazury region's image. The research material collected allowed, following an application of selected research methods, to achieve the majority of the research objectives.

This publication is a response to the local authorities' demand for a novel academic solution of the issue of promotion strategy model development. The research carried out herein is of a multi-disciplinary nature. The application of a process and systemic approach to the development of the model of the strategy of region's image management necessitates the use of the current achievements of administration, management and marketing sciences.

Moreover, the demonstrated method has a general character, which makes it applicable also to units other than those studies, above all, to NUTS2 level units in other regions. The presented overview of the range of issues in the analyzed field does not exhaust all crucial matters.

The research allowed to determine the strategic factors of the promotion strategy used by the WarmińskoMazurskie Province. The effectiveness of promotional activities conducted by self-government units of the Warmia and Mazury region has been previously tested on a group of tourists. The long-term Masuria Miracle of Nature campaign was described as highly effective. By. The models of promotion strategies presented in the course of research have a key role here, as well as formal and informal connections with business partners and all aspects of such cooperation. This is confirmed by other studies of science representatives, which say that under economic conditions, one of the most strategically effective and realistic ways is to consolidate small creative, innovation-focused enterprises around integrated establishments, which should involve the provision of statutory support for these concentration processes and proper coordination on the part of public authorities (Ignatavičius et al. 2015; Tvaronavičiené, Černevičiūtė, 2015; Valter 2016; Tvaronavičienė, 2017; Razminienė, Tvaronavičienė 2017; Monni et al., 2017; Goncharenko et al., 2019; Petrenko et al., 2019).

Therefore, the author intends to pursue the analysis of the studied issue as part of other individual research works. 


\section{ENTREPRENEURSHIP AND SUSTAINABILITY ISSUES}

ISSN 2345-0282 (online) http://jssidoi.org/jesi/

2019 Volume 7 Number 2 (December)

http://doi.org/10.9770/jesi.2019.7.2(32)

\section{References}

Asparouhov, T., Muthen, B. 2009. Exploratory Structural Equation Modeling, Structural Equation Modeling, 16, $397-438$.

Chrząścik M. 2018. Quality management principles as a factor strengthening the image of a territorial unit, Zeszyty Naukowe Uniwersytetu Przyrodniczo-Humanistycznego $w$ Siedlcach. Seria: Administracja $i \quad$ Zarzadzanie. $43 \quad$ (116), https://repozytorium.uph.edu.pl/bitstream/handle/11331/2015/Chrzascik.M.Zasady_zarzadzania_jakoscia_jako_czynnik_wzmacniania_wiz erunku_jednostki_terytorialnej.pdf?sequence $=1$

Domański T., 1997. Marketing terytorialny: strategiczne wyzwania dla miast i regionów (Territorial marketing: strategic challenges for the cities and regions), Łódź, Centrum Badań i Studiów Francuskich Uniwersytetu Łódzkiego, p. 19.

Glińska, E., Florek, M., Kowalewska, A. 2009. Wizerunek miasta od koncepcji do wdrożenia (City image - from concept building the implementation), Warszawa, p. 31.

Goncharenko, O., Tohochynskyi, O., Sirenko, K., Chebonenko, S., Tretiak, H. 2019. Innovative performance as precondition of sustainable and secure development. Journal of Security and Sustainability Issues, 8(3), 531-544. https://doi.org/10.9770/jssi.2019.8.3(19)

Grzegorczyk, A., Kochaniec, A. 2010. Kreowanie wizerunku miast (Creating image of the city), Warszawa, Kozak Druk, p. 132.

Ignatavičius, R., Tvaronavičienè, M., Piccinetti, L. 2015. Sustainable development through technology transfer networks: case of Lithuania. Journal of Security and Sustainability Issues, 4(3), 261-267. http://dx.doi.org/10.9770/jssi.2015.4.3(6)

Jucker, R., Mathar, R. (eds). 2015. Schooling for Sustainable Development in Europe. Concepts, Policies and Educational Experiences at the End of the UN Decade of Education for Sustainable Development, Springer.

Konarski, R. 2019. Modele równań strukturalnych. Teoria i praktyka...(Structural equation models. Theory and practice...), op. cit., p. 128.

Li, Y., Gouhui, S., Eppler, M. J. 2008. Making Strategy Work: A literature Review on the Factors influencing Strategy Implementation, ICA Working Paper 2/2008, Svirezza, Universita della Svizzera italiana, p. 29.

Petrenko, Y., Vechkinzova, E., Antonov, V. 2019. Transition from the industrial clusters to the smart specialization of the regions in Kazakhstan. Insights into Regional Development, 1(2), 118-128. https://doi.org/10.9770/ird.2019.1.2(3)

Polozova, T., Musiienko, V., Storozhenko, O., Peresada, O., Geseleva, N. 2019. Modeling of energy-saving processes in the context of energy safety and security. Journal of Security and Sustainability Issues, 8(3), 387-397. https://doi.org/10.9770/jssi.2019.8.3(8)

Raport COMCEC, Effective Tourism Marketing Strategies, COCMCEC, Ankara 2015, p. 4.

Razminienė, K., Tvaronavičienė, M. 2017. Economic globalization and its impacts on clustering. Terra Economicus, 15(2), 109-121. http://doi.org/10.23683/2073-6606-2017-15-2-109-121clustering.html

Skrzypek, E. 2000. Jakość i efektywność (Quality and Effectiveness), Wydawnictwo Uniwersytetu Marii Curie-Skłodowskiej, Lublin, 190 p.

Smaliukienė, R., Monni, S. 2019. A step-by-step approach to social marketing in energy transition. Insights into Regional Development, 1(1), 19-32. https://doi.org/10.9770/ird.2019.1.1(2)

StatSoft, Inc., 2010. STATISTICA (data analysis software system), version 9.1.

Szromnik A., 2008. Marketing terytorialny. Miasto i region na rynku (Territorial marketing. The city and the region on the market.), Kraków, Oficyna Wolters Kluwer Business, pp. 56-57.

Tkachenko, V., Kwilinski, A., Korystin, O., Svyrydiuk, N., Tkachenko, I. 2019. Assessment of information technologies influence on financial security of economy. Journal of Security and Sustainability Issues, 8(3), 375-385. https://doi.org/10.9770/jssi.2019.8.3(7)

Tvaronavičienė M., Černevičiūtè, J. 2015. Technology transfer phenomenon and its impact on sustainable development. Journal of Security 


\section{ENTREPRENEURSHIP AND SUSTAINABILITY ISSUES}

ISSN 2345-0282 (online) http://jssidoi.org/jesi/

2019 Volume 7 Number 2 (December)

http://doi.org/10.9770/jesi.2019.7.2(32)

and Sustainability Issues, 5(1), 87-97. http://dx.doi.org/10.9770/jssi.2015.5.1(7)

Tvaronavičienè, M. 2017. Clusters, innovations and energy efficiency: if relantionship could be traced. Marketing and Management of Innovations, 2, 382 - 391 http://doi.org/10.21272/mmi.2017.2-35

Tvaronavičienè, M., Razminienė K., 2017. Towards competitive regional development through clusters: approaches to their performance evaluation. Journal of Competitiveness, 9(4), 133 - 147. https://doi.org/10.7441/joc.2017.04.09

Ul Haque, A., Kot, S., Imran, M. 2019. The moderating role of environmental disaster in relation to microfinance's non-financial services and women's micro-enterprise sustainability. Journal of Security and Sustainability Issues, 8(3), 355-373. https://doi.org/10.9770/jssi.2019.8.3(6)

Valter, N., Androniceanu, A., Dragulanescu, I.V., Duca, M. Agile management based on modularization of products and processes, Proceedings of BASIQ International Conference - New Trends in Sustainable Business and Consumption, 2-3 June, 2016, Konstanz, Germany, Book series: Proceedings of BASIQ, pp: 310-318, Edited by: Rodica Pamfilie, Vasile Dinu, Laurențiu Tăchiciu, Doru Pleșea, Cristinel Vasiliu; ISSN 2457-483X.

\section{Aknowledgements}

The research was carried out under the research theme No. 432/15/S financed from by a science grant provided by the Ministry of Science and Higher Education of Poland.

Marcin CHRZĄŚCIK - The Doctor of Economic Sciences in Field Management. An employee of Faculty of Economic and Legal Sciences of Siedlce University of Natural Sciences and Humanities. He graduated PhD from the Faculty of Management of Warsaw University of Technology. In the years 2010 - 2016 he was the Director of the Institute of Multimedia Design of Warsaw College of romotion. Author of over thirty marketing-related publications. He took part in many scientific projects. He is interested in territorial marketing, neuro-marketing, multimedia design, research methods using modern IT tools.

ORCID ID: $\underline{\text { https://orcid.org/0000-0002-8982-1213 }}$

Copyright (C) 2019 by author(s) and VsI Entrepreneurship and Sustainability Center

This work is licensed under the Creative Commons Attribution International License (CC BY). http://creativecommons.org/licenses/by/4.0/

(c) (i) Open Access

